\title{
Reduced reproductive compatibility in Arianta arbustorum (Gastropoda) from distant populations
}

\author{
BRUNO BAUR \& ANETTE BAUR \\ Institute of Zoology, University of Basel, Rheinsprung 9, CH-4051 Basel, Switzerland
}

\begin{abstract}
Reproductive isolation was examined in the simultaneously hermaphroditic, self-incompatible land snail Arianta arbustorum. We tested individuals from two geographically isolated populations in Sweden and three populations in Switzerland. In mate-choice tests, within-population (homotypic) and between-population (heterotypic) meetings occurred among snails in frequencies expected by chance. We found no significant difference in courtship latency and courtship duration between homotypic and heterotypic pairs. However, snails from three populations preferred to mate with homotypic partners. Mating preferences could partly be explained by differences in mating propensity in two out of three populations, but not in matings between a Swedish and a Swiss population. Cross breeding demonstrated a high degree of reproductive compatibility between these two distant populations. In contrast, heterotypic pairs involving two Swiss populations had a reduced fertility. The experimental results indicate that partial premating and postmating isolation may exist between distant populations of $A$. arbustorum. However, the degree of isolation is not related to the geographical distance between populations.
\end{abstract}

Keywords: courtship, fecundity, gastropod, isolation, mate choice, reproductive compatibility.

\section{Introduction}

Both theoretical and empirical evidence indicate that species with continuous and widespread distributions are unlikely to be genetically homogeneous across their entire range and often contain incipient parapatric species (Mayr, 1963; Endler, 1977; Otte \& Endler, 1989). Reproductive isolation may arise in a wide variety of ways; but most likely it will be built up gradually, in a series of small steps (Barton \& Charlesworth, 1984). In land snails, limited dispersal capacity and restricted habitat requirements may enhance the process of adaptation to local conditions. As a consequence, reproductive isolation may develop between distant populations which are exposed to different selection pressures.

The helicid land snail, Arianta arbustorum (L.), has a continuous distribution across Europe from the Alps to northern Scandinavia (Kerney \& Cameron, 1979). It has been surmised that $A$. arbustorum recolonized the Alps and Scandinavia from source populations in Germany following the retreating glaciers in the Würm late-glacial (Ant, 1969; Waldén, 1986; Arter, 1990). It shows polymorphism, as well as continuous variation both in shell and body colour (Kerney \& Cameron, 1979; Burla \& Stahel, 1983). Enzyme electrophoresis has revealed a high degree of genetic differentiation among isolated populations (Vismara, 1983; Arter, 1990). Furthermore, distant populations exhibit great differences in life-history characters including shell size, maturation time, egg size, clutch size, and longevity, and in behavioural traits such as resting-site preference and dispersal tendency (Baur, 1984, 1986; Baur \& Gosteli, 1986; Baur \& Raboud, 1988; Baur, 1990).

In this paper, we present results of experiments designed to investigate premating and postmating reproductive isolation in distant populations of $A$. arbustorum. To examine whether behaviour causes premating isolation, we monitored the courtship process of individuals from different populations in matechoice tests. Breeding experiments were carried out to determine whether heterotypic crosses have a reduced fertility. 


\section{Materials and methods}

\section{Study organism}

Arianta arbustorum is a simultaneously hermaphroditic, self-incompatible helicid land snail that is common in moist habitats of north-western and central Europe. Individuals become sexually mature at an age of 2-4 years and then live on average 3-4 years as adults, but life spans of up to 14 years have been recorded (Baur \& Raboud, 1988). In the field, snails deposit 1-3 clutches consisting each of 20-50 eggs in each reproductive season (Baur \& Raboud, 1988; Baur 1990).

Mating behaviour in A. arbustorum includes introductory behaviour (foreplay) with reciprocal tactile and oral contacts, and curving turns to reach an optimal position with respect to the genital opening of the partner (Hofmann, 1923; B. Baur, unpublished observations). This is followed by dart shooting, i.e. the pushing of a calcareous dart into the matings partner's body, which is assumed to facilitate mating by increasing behavioural synchrony (cf., Adamo \& Chase, 1990). Finally, the copulation is reciprocal; spermatophores are transferred after simultaneous intromission. Arianta arbustorum mates repeatedly in the course of a reproductive season, and sperm can be stored for more than 1 year (Baur, 1988).

\section{Collection of animals}

Five groups of $A$. arbustorum, referred to as populations for convenience, were collected from two sites in Sweden (referred to as $S_{1}$ and $S_{2}$ ) and from three sites in the Swiss Alps $\left(\mathrm{CH}_{1}-\mathrm{CH}_{3}\right)$, all in September 1987.

$\mathrm{S}_{1}$ : Uppsala, central Sweden $\left(59^{\circ} 51^{\prime} \mathrm{N}, 17^{\circ} 40^{\prime} \mathrm{E}\right)$. Clearing with rough herbage (mainly Cirsium arvense) in a pine-dominated forest.

$\mathrm{S}_{2}$ : Landvetter, near Gothenburg, south-western Sweden $\left(57^{\circ} 41^{\prime} \mathrm{N}, 12^{\circ} 13^{\prime} \mathrm{E}\right)$. Embankment of a road, covered by rough herbage (Dactylis sp., $C$. arvense), $400 \mathrm{~km}$ south-west of $S_{1}$.

$\mathrm{CH}_{1}$ : Gurnigel, near Berne, Switzerland $\left(46^{\circ} 44^{\prime} \mathrm{N}, 7^{\circ}\right.$ $27^{\prime} \mathrm{E}$ ). Overgrown clearing with rough herbage in a pine forest $(1430 \mathrm{~m}$ a.s.l.). Approximately $1600 \mathrm{~km}$ south-west of $S_{1}$.

$\mathrm{CH}_{2}$ : Gantrisch, near Berne, Switzerland $\left(46^{\circ} 42^{\prime} \mathrm{N}\right.$, $\left.7^{\circ} 27^{\prime} \mathrm{E}\right)$. Alpine pasture at $1810 \mathrm{~m}$ a.s.l., $4 \mathrm{~km}$ south of $\mathrm{CH}_{1}$.

$\mathrm{CH}_{3}$ : Strela, near Davos, Switzerland $\left(46^{\circ} 49^{\prime} \mathrm{N}, 9^{\circ} 48^{\prime}\right.$ E). Alpine pasture with scattered scree at 2100 m a.s.l., $180 \mathrm{~km}$ east of $\mathrm{CH}_{1}$ and $\mathrm{CH}_{2}$.

At each site fully grown $A$. arbustorum were collected within an area of $20 \times 20 \mathrm{~m}$ except at $\mathrm{S}_{2}$, where snails were collected in an area measuring $40 \times 5 \mathrm{~m}$ along the road. The size of each adult snail was determined by measuring its maximum shell breadth to the nearest $0.1 \mathrm{~mm}$ using a vernier caliper. The shell breadth of A. arbustorum from populations $\mathrm{S}_{1}$, used in the mate-choice tests, averaged $21.1 \mathrm{~mm}$ (s.d. $=0.9$, range $18.9-23.2 \mathrm{~mm}, n=71$ ). Corresponding figures for snails of population $\mathrm{S}_{2}$ were $19.5 \mathrm{~mm}$ $(0.8,17.9-21.5 \mathrm{~mm}, n=33)$, for population $\mathrm{CH}_{1} 17.5$ $\mathrm{mm}(0.7,16.0-19.0 \mathrm{~mm}, n=37)$, for population $\mathrm{CH}_{2}$ $17.3 \mathrm{~mm}(0.8,15.0-18.8 \mathrm{~mm}, n=42)$, and for population $\mathrm{CH}_{3} 17.1(0.7,14.4-18.8 \mathrm{~mm}, n=41)$. Snails from different populations differed in shell size (one-way ANOVA, $F=252.44$, d.f. $=223, P<0.0001$ ). In pairwise comparisons snails from the population $S_{1}$ were larger than those from the populations $\mathrm{S}_{2}$ and $\mathrm{CH}_{1}$ (Scheffé's test; $\mathrm{S}_{1}$ vs. $\mathrm{S}_{2}, P<0.01 ; \mathrm{S}_{1}$ vs. $\mathrm{CH}_{1}, P<0.001$ ), whereas snails from the populations $\mathrm{CH}_{2}$ and $\mathrm{CH}_{3}$ did not differ in shell breadth (Scheffé's test; $\mathrm{CH}_{2}$ vs. $\mathrm{CH}_{3}, P>0.3$ ).

\section{Mate-choice tests}

Adult snails were marked individually by writing numbers on their shells with a waterproof felt-tipped pen on a spot of correction fluid (Tipp-Ex). The animals showed no visible reaction to the marking procedure. They were kept individually isolated in glass jars of $8.5 \mathrm{~cm}$ diameter outdoors in a shaded place near Uppsala for approximately 1 month. The bottom of each container was covered with moist soil mixed with powdered lime. Lettuce was available ad libitum. At the end of October the snails were allowed to hibernate in their containers at $4^{\circ} \mathrm{C}$ and in darkness.

In the following spring mate-choice tests were conducted to examine whether premating isolation occurs among distant populations of $A$. arbustorum. Three snails from each of two different populations were placed in a test arena (a transparent plastic container measuring $24.7 \times 18 \times 7 \mathrm{~cm}$ ). Its bottom was covered with moist paper towelling to facilitate snail activity. Active snails (individuals with extended soft body and everted tentacles) were randomly assigned to a trial. The observation room had overhead lighting and a temperature ranging from $20-23^{\circ} \mathrm{C}$.

The snails' courtship behaviour was monitored using a stop-watch. Records were taken of the number and duration of homo- and heterotypic meetings, time until initiation of courtship (courtship latency), and duration of courtship (time interval from courtship initiation to copulation). The initiation of courtship was defined as the first simultaneous oral contact (which was usually accompanied by a slight eversion of the penial lobe in one of the snails). The beginning of copulation was defined as the first simultaneous intromission. Observation sessions were terminated when the first copula- 
tion occurred in a trial, or after $8 \mathrm{~h}$ if no snail initiated courtship behaviour. The major reason to follow this design was that when two out of six snails were already mating, the available choices for the remaining four had drastically changed, which complicated the analysis. Individuals involved in copulations were excluded from further tests. Individuals that did not initiate courtship behaviour were tested again 10-14 days later using a new set of snails. As a measure for mating propensity we used the percentage of snails mating in all trials. For statistical analyses we used only records from mating pairs.

The following mate-choice tests were conducted:(1) $\mathrm{S}_{1} \times \mathrm{S}_{2}$, (2) $\mathrm{S}_{1} \times \mathrm{CH}_{1}$, and (3) $\mathrm{CH}_{2} \times \mathrm{CH}_{3}$. The number of trials for each test is given in Table 2. In all, 73 trials lasting $512 \mathrm{~h}$ were run.

Each successful mating was analysed to examine whether particular elements of behaviour influenced the snails' choice. The courtship behaviour of individuals involved in heterotypic matings was compared with that of snails in homotypic matings. Assuming non-discriminatory behaviour among individuals, the probability of homotypic encounters is 0.4 and that for heterotypic encounters 0.6 in the experimental design described above. Assuming random mating among individuals, the probability for heterotypic pair formation is $(0.5 \times 0.6)+(0.5 \times 0.6)=0.6$ and $2 \times(0.5 \times 0.4)=0.4$ for homotypic pair formation $(0.2$ for both populations). We also calculated a second kind of expected frequency of pair formation which takes into account differences in mating propensity. Deviations from random mating were evaluated using chisquared tests (Sokal \& Rohlf, 1981).

\section{Breeding experiment}

A breeding experiment was designed to examine whether reproductive postmating isolation occurs among snails from the populations $\mathrm{S}_{1}, \mathrm{CH}_{1}, \mathrm{CH}_{2}$ and $\mathrm{CH}_{3}$. All the animals used in the experiment were collected as juveniles in the sites described above in the summer of 1988 and maintained in isolation until they became sexually mature. Thirty-six individuals from each source population were crossed as follows: 12 $\mathrm{S}_{1} \times \mathrm{S}_{1}, \quad 12 \mathrm{~S}_{1} \times \mathrm{CH}_{1}, \quad 12 \mathrm{CH}_{1} \times \mathrm{CH}_{1}$, and 12 $\mathrm{CH}_{2} \times \mathrm{CH}_{2}, 12 \mathrm{CH}_{2} \times \mathrm{CH}_{3}$ and $12 \mathrm{CH}_{3} \times \mathrm{CH}_{3}$.

Virgin snails were randomly assigned to a mating partner from the appropriate source population. Pairs were kept in transparent plastic boxes measuring $12.5 \times 9 \times 5 \mathrm{~cm}$. The bottom of the boxes was covered with moist soil mixed with powdered lime. Snails were maintained on a $\mathrm{L}: \mathrm{D} 16: 8 \mathrm{~h}$ photoperiod at $19^{\circ} \pm 1^{\circ} \mathrm{C}$. Lettuce was available ad libitum.

The boxes were checked weekly for eggs. Eggs were counted and incubated in plastic dishes lined with moist paper towelling at $19^{\circ} \mathrm{C}$. Newly hatched snails were daily separated from remaining unhatched eggs to prevent egg cannibalism (cf., Baur \& Baur, 1986).

The breeding experiment was established in the summer of 1989 and was run until September 1990. During winter, the snails were allowed to hibernate for 6 months at $4^{\circ} \mathrm{C}$. As snails from different populations did not reach sexual maturity simultaneously in the first year, we only considered reproduction from the second year in the data analyses. Furthermore, some snails died during the experiment and were therefore excluded from data analysis.

\section{Results}

\section{Mate-choice tests}

Snail movements in the test arena were seemingly random. When two individuals met, mutual tactile contacts with tentacles occurred. Either the snails separated within $5.5 \pm 0.6$ min (mean \pm s.e., range $1-15$ min, $n=55$ ), or courtship commenced with oral contact. Homotypic and heterotypic meetings occurred in frequencies expected by chance (chi-squared test based on total numbers, in all populations $P>0.1$ ). The number of potential mating partners $(x)$ encountered prior to courtship initiation with the eventual mate ranged from 0 to 11 (median 3; including repeated counts); its frequency distribution fitted a function with exponential decay $\left(y=27.15 \mathrm{e}^{-0.305 x}\right.$, $r^{2}=0.916$, d.f. $\left.=10, P<0.001\right)$. Twenty out of the 98 snails (20.4 per cent) that were engaged in copulations in the tests mated with the first partner encountered [13 individuals (18.1 per cent) with a homotypic partner and 7 (26.9 per cent) with a heterotypic partner]. Final mate choice (whether homotypic or heterotypic) was not influenced by the number of snails encountered prior to mating (Mann-Whitney $U$-test, $P>0.1$ ). Furthermore, snail size had no influence on the number of homotypic and heterotypic encounters (Spearman correlation; in all populations, $P>0.2$ ).

Courtship did not always lead to copulation. Twenty-six out of the 98 snails had courted unsuccessfully with another potential partner before they initiated courtship with their eventual mate. Courtship was more frequently broken off in heterotypic pairs (in 10 out of 23 cases; 43.5 per cent) than in homotypic pairs (in three out of 39 cases; 7.7 per cent) $\left(\chi^{2}=11.18\right.$, d.f. $=1, P<0.001$ ).

Pair formation deviated significantly from random mating (Table 1). In all tests, fewer heterotypic matings occurred than expected under random mating, indicating partial premating isolation. In the $\mathrm{S}_{1} \times \mathrm{S}_{2}$ and $\mathrm{CH}_{2} \times \mathrm{CH}_{3}$ tests, however, there were also fewer homotypic matings involving $\mathrm{S}_{1}$ and $\mathrm{CH}_{2}$ individuals 
Table 1 Results of mate-choice experiments with A. arbustorum from five distant populations

\begin{tabular}{|c|c|c|c|c|c|c|c|c|c|}
\hline Test & $\begin{array}{l}\text { Number of } \\
\text { matings }\end{array}$ & $\begin{array}{l}\text { Mating } \\
\text { pairs }\end{array}$ & $\begin{array}{l}\text { Observed } \\
\text { number of } \\
\text { matings }\end{array}$ & $\begin{array}{l}\text { Expected } \\
\text { for random } \\
\text { mating* }\end{array}$ & $\chi^{2} \dagger$ & $P$ & $\begin{array}{l}\text { Expected matings } \\
\text { with different } \\
\text { mating propensity } \ddagger\end{array}$ & $\chi^{2} \dagger$ & $P$ \\
\hline \multirow[t]{3}{*}{$\mathrm{S}_{1} \times \mathrm{S}_{2}$} & \multirow[t]{3}{*}{13} & $S_{1} \times S_{1}$ & 1 & 2.6 & \multirow{4}{*}{14.05} & \multirow{4}{*}{$<0.001$} & 0.5 & \multirow{4}{*}{1.13} & \multirow{4}{*}{ ns } \\
\hline & & $\mathrm{S}_{1} \times \mathrm{S}_{2}$ & 4 & 7.8 & & & 5.6 & & \\
\hline & & $\mathrm{S}_{2} \times \mathrm{S}_{2}$ & 8 & 2.6 & & & 6.9 & & \\
\hline \multirow{3}{*}{$\mathrm{S}_{1} \times \mathrm{CH}_{1}$} & 22 & $\mathrm{~S}_{1} \times \mathrm{S}_{1}$ & 7 & 4.4 & & & 2.6 & & \\
\hline & & $\mathrm{S}_{1} \times \mathrm{CH}_{1}$ & 3 & 13.2 & \multirow[t]{2}{*}{22.55} & \multirow[t]{2}{*}{$<0.001$} & 12.6 & \multirow[t]{2}{*}{18.53} & \multirow[t]{2}{*}{$<0.001$} \\
\hline & & $\mathrm{CH}_{\mathrm{i}} \times \mathrm{CH}_{\mathrm{l}}$ & 12 & 4.4 & & & 6.9 & & \\
\hline \multirow[t]{3}{*}{$\mathrm{CH}_{2} \times \mathrm{CH}_{3}$} & 14 & $\mathrm{CH}_{2} \times \mathrm{CH}_{2}$ & 1 & 2.8 & \multirow{3}{*}{8.14} & \multirow{3}{*}{$<0.01$} & 0.9 & \multirow{3}{*}{0.26} & \multirow{3}{*}{ ns } \\
\hline & & $\mathrm{CH}_{2} \times \mathrm{CH}_{3}$ & 6 & 8.4 & & & 7.0 & & \\
\hline & & $\mathrm{CH}_{3} \times \mathrm{CH}_{3}$ & 7 & 2.8 & & & 6.2 & & \\
\hline
\end{tabular}

*Expected frequencies do not take into account differences in mating propensity. $\dagger$ d.f. $=1$ in all cases.

$\ddagger$ Obtained by weighing the expected frequencies for random pair formation with the mating propensities given in Table 2 .

Table 2 Mating propensity (percentage of individuals mating) in A. arbustorum from five populations

\begin{tabular}{llllll}
\hline Test & Number of trials* & Population & $\begin{array}{l}\text { Mating propensity } \\
(\%)\end{array}$ & $\chi^{2}$ & $P$ \\
\hline $\mathrm{S}_{1} \times \mathrm{S}_{2}$ & 20 & $\left\{\begin{array}{ll}\mathrm{S}_{1} & 10.0 \dagger \\
\mathrm{S}_{2} & 33.3\end{array}\right\}$ & 9.62 & $<0.01$ \\
$\mathrm{~S}_{1} \times \mathrm{CH}_{1}$ & 30 & $\left\{\begin{array}{ll}\mathrm{S}_{1} & 18.8 \dagger \\
\mathrm{CH}_{1} & 30.0\end{array}\right\}$ & 3.04 & 0.08 \\
$\mathrm{CH}_{2} \times \mathrm{CH}_{3}$ & 23 & $\left\{\begin{array}{ll}\mathrm{CH}_{2} & 11.6 \\
\mathrm{CH}_{3} & 29.0\end{array}\right\}$ & 6.45 & $<0.02$ \\
\hline
\end{tabular}

*In each trial three individuals from each of two populations were tested (see Methods).

$\dagger$ The mating propensity of $S_{1}$ does not differ between the two tests $\left(\chi^{2}=2.19\right.$, d.f. $=1, P>0.1$ ).

than expected under random mating (Table 1). Deviations from random mating can partly be explained by between-population differences in mating propensity (percentage of individuals mating). Individuals from populations $\mathrm{S}_{2}, \mathrm{CH}_{1}$ and $\mathrm{CH}_{3}$ mated 1.6-3.3 times as frequently as did those from populations $\mathrm{S}_{1}$ and $\mathrm{CH}_{2}$ (Table 2). As a result, more homotypic matings occurred in the populations $\mathrm{S}_{2}\left(\mathrm{~S}_{1} \times \mathrm{S}_{2}\right.$ tests $)$ and $\mathrm{CH}_{3}$ $\left(\mathrm{CH}_{2} \times \mathrm{CH}_{3}\right.$ tests $)$. 'However, homotypic matings also occurred in excess in the populations $\mathrm{S}_{1}$ and $\mathrm{CH}_{1}$ $\left(\mathrm{S}_{1} \times \mathrm{CH}_{1}\right.$ tests) even after differences in mating propensity were controlled for, indicating premating reproductive isolation (Table 1).

Courtship latency did not differ significantly between homotypic and heterotypic matings (Table 3; Mann-Whitney $U$-test, in all comparisons $P>0.1$ ). Furthermore, courtship duration did not differ between heterotypic and homotypic matings (Table 3; Mann-Whitney $U$-test, in all comparisons $P>0.4$ ).

\section{Breeding experiment}

In the $\mathrm{S}_{1} \times \mathrm{CH}_{1}$ breeding, heterotypic and homotypic crosses differed neither in the number of clutches produced, nor in clutch size and hatching success (Table 4). In the $\mathrm{CH}_{2} \times \mathrm{CH}_{3}$ breeding, heterotypic crosses produced smaller clutches with a lower hatching success than did homotypic crosses from population $\mathrm{CH}_{2}$ (Table 4).

Table 5 shows the number of hatchlings that emerged from homo- and heterotypic crosses. In the $\mathrm{S}_{1} \times \mathrm{CH}_{1}$ breeding, heterotypic pairs produced as many offspring as did homotypic crosses. This indicates that individuals of both populations separated by 
$1600 \mathrm{~km}$ have maintained reproductive compatibility. In the $\mathrm{CH}_{2} \times \mathrm{CH}_{3}$ breeding, fewer hatchlings derived from heterotypic than from homotypic crosses of the population $\mathrm{CH}_{2}$, suggesting a reduced compatibility. The number of hatchlings deriving from heterotypic crosses differed from the average number of young of both homotypic crosses, when all pairs were considered. However, when pairs that failed to reproduce were excluded from the analysis, the number of hatchlings produced by heterotypic crosses did not differ from the average number of young from both homotypic crosses (Table 5). Considering all crosses, five of the 55 pairs failed to produce any offspring at all: two homotypic pairs (5.6 per cent) and three heterotypic pairs (15.8 per cent) (Table 5).

Table 3 Courtship latency and courtship duration in matechoice experiments with $A$. arbustorum. Values are means (1 s.e.)

\begin{tabular}{lrrl}
\hline $\begin{array}{l}\text { Mating } \\
\text { pairs }\end{array}$ & $n$ & $\begin{array}{l}\text { Courtship } \\
\text { latency (min) }\end{array}$ & $\begin{array}{l}\text { Courtship } \\
\text { duration (min) }\end{array}$ \\
\hline $\mathrm{S}_{1} \times \mathrm{S}_{1}$ & 1 & $27.0-$ & $184.2-$ \\
$\mathrm{S}_{1} \times \mathrm{S}_{2}$ & 4 & $221.2(10.1)$ & $273.0(43.0)$ \\
$\mathrm{S}_{2} \times \mathrm{S}_{2}$ & 8 & $229.9(59.2)$ & $257.8(52.0)$ \\
$\mathrm{S}_{1} \times \mathrm{S}_{1}$ & 7 & $198.8(46.4)$ & $309.9(66.4)$ \\
$\mathrm{S}_{1} \times \mathrm{CH}_{1}$ & 3 & $81.6(41.0)$ & $241.6(39.1)$ \\
$\mathrm{CH}_{1} \times \mathrm{CH}_{1}$ & 12 & $151.2(32.6)$ & $308.7(34.1)$ \\
$\mathrm{CH}_{2} \times \mathrm{CH}_{2}$ & 1 & $211.8-$ & $120.0-$ \\
$\mathrm{CH}_{2} \times \mathrm{CH}_{3}$ & 6 & $84.7(17.8)$ & $197.6(33.1)$ \\
$\mathrm{CH}_{3} \times \mathrm{CH}_{3}$ & 7 & $181.1(45.6)$ & $217.8(26.6)$ \\
\hline
\end{tabular}

The number of hatchlings produced varied greatly within each group of matings; even when pairs that failed to produce any offspring were excluded, the number of offspring per pair showed two- to 20 -fold differences within each group. In both breeding experiments, the group of heterotypic pairs showed a variation twice as high as those in the corresponding group of homotypic pairs. Due to the great within-group variation, it is difficult to assess the real extent of differences in the number of offspring produced between the groups.

\section{Discussion}

Observations of courtship interactions between members of different populations have received relatively little attention in the long history of quantifying reproductive isolation between strains, races or species (reviewed in Spieth \& Ringo, 1983; Verrell \& Arnold, 1989). The immediate benefit of such behavioural observations is to aid in the identification of the stage(s) of breakdown in courtship encounters; such knowledge in turn can lead to tests of hypotheses about the morphological structures and behaviour patterns involved in the avoidance of hybridization (Verrell \& Arnold, 1989). Thus, the observation of courtship encounters between individuals of geographically isolated populations might be a prerequisite to experimental studies of the behavioural basis of reproductive isolation.

The present study demonstrated that individuals of $A$. arbustorum met homotypic and heterotypic potential mates in frequencies expected by chance. However, there was a tendency for snails with the same origin to mate preferentially with one another. Any discrimina-

Table 4 Number of clutches, clutch size and hatching success in homo- and heterotypic crosses of $A$. arbustorum

\begin{tabular}{|c|c|c|c|c|}
\hline Cross type & $\begin{array}{l}\text { Number of } \\
\text { pairs }\end{array}$ & $\begin{array}{l}\text { Number of clutches } \\
\text { per pair }\end{array}$ & Clutch size & $\begin{array}{l}\text { Hatching } \\
\text { success }(\%)\end{array}$ \\
\hline$S_{1} \times S_{1}$ & 9 & $8.9(1.3)$ & $25.7(3.2)$ & $24.3(3.9)$ \\
\hline $\mathrm{S}_{1} \times \mathrm{CH}_{1}$ & 8 & $7.5(1.0)^{\mathrm{ns}}$ & $22.0(3.2)^{\mathrm{ns}}$ & $45.9(8.8)^{\text {ns }}$ \\
\hline $\mathrm{CH}_{1} \times \mathrm{CH}_{1}$ & 8 & $9.6(1.3)^{\mathrm{ns}}$ & $17.9(1.4)^{\mathrm{nS}}$ & $41.4(4.2)^{\mathrm{ns}}$ \\
\hline $\mathrm{CH}_{2} \times \mathrm{CH}_{2}$ & 9 & $12.1(0.9)$ & $27.9(1.7)$ & $52.9(2.5)$ \\
\hline $\mathrm{CH}_{2} \times \mathrm{CH}_{3}$ & 8 & $8.8(1.3)^{*}$ & $18.9(2.4)^{* * *}$ & $30.8(5.7)^{* * *}$ \\
\hline $\mathrm{CH}_{3} \times \mathrm{CH}_{3}$ & 8 & $6 \cdot 1(0.9)^{\mathrm{ns}}$ & $26.9(3.7)^{\mathrm{ns}}$ & $46.6(6.5)^{\mathrm{ns}}$ \\
\hline
\end{tabular}

Data are means ( 1 s.e.). $P=$ values for intercross comparisons result from $t$-tests or Mann-Whitney $U$-tests [hatching success].

${ }^{*} P<0.05,{ }^{* *} P<0.01, \mathrm{~ns}=$ not significant. 
Table 5 Number of hatchlings in homo- and heterotypic crosses of A. arbustorum

\begin{tabular}{|c|c|c|c|c|}
\hline Cross type & $\begin{array}{l}\text { Number of } \\
\text { pairs }\end{array}$ & $\begin{array}{l}\text { Number of } \\
\text { hatchlings } \\
\text { per pair }\end{array}$ & $\begin{array}{l}\text { Number of pairs } \\
\text { with successful } \\
\text { matings }\end{array}$ & $\begin{array}{l}\text { Number of } \\
\text { hatchlings } \\
\text { per pair }\end{array}$ \\
\hline$S_{1} \times S_{1}$ & 10 & $63.6(13.5)$ & 9 & $70.7(12.9)$ \\
\hline $\mathrm{S}_{1} \times \mathrm{CH}_{1}$ & 9 & $87.5(28.8)^{\text {nS }}$ & 8 & $98.4(30.2)^{\mathrm{ns}}$ \\
\hline $\mathrm{CH}_{1} \times \mathrm{CH}_{1}$ & 8 & $91.4(16.7)^{\text {ns }}$ & 8 & $91.4(16.7)^{\mathrm{ns}}$ \\
\hline $\mathrm{CH}_{2} \times \mathrm{CH}_{2}$ & 9 & $189.3(20.2)$ & 9 & $189.3(20.2)$ \\
\hline $\mathrm{CH}_{2} \times \mathrm{CH}_{3}$ & 10 & $69.1 \dagger(23.1)^{* *}$ & 8 & $86.4 \ddagger(25.4)^{*}$ \\
\hline $\mathrm{CH}_{3} \times \mathrm{CH}_{3}$ & 9 & $71.3(14.0)^{\mathrm{ns}}$ & 8 & $80.3(12.2)^{\mathrm{ns}}$ \\
\hline
\end{tabular}

Data are means ( 1 s.e.). $P=$ values for intercross comparisons result from $t$-tests.

** $P<0.01, \mathrm{~ns}=$ not significant.

$\dagger$ The number of hatchlings in heterotypic crosses differs significantly from the mean value of both homotypic crosses (130.3 hatchlings; $t=2.649$, d.f. $=9, P<0.05$ ).

$\ddagger$ The number of hatchlings in heterotypic crosses does not differ from the mean value of both homotypic crosses (134.8 hatchlings; $t=1.906$, d.f. $=7, P=0.09$ ).

tion exercised by a courting snail will be the result of two sets of factors. The first, which is strictly concerned with sexual isolation, will depend on the ability of snails to recognize minute differences in courtship behaviour. The second is concerned with the mating propensity of the snails, which may mask or exaggerate the outcome of mate-choice tests. We used the percentage of individuals from each population that mated in the trials as a measure of mating propensity. This is an indirect measure of mating frequency. The more active a snail is, the more likely it will initiate courtship. Differences in the frequencies of homotypic matings in the tests with $\mathrm{S}_{1}$ and $\mathrm{S}_{2}$, as well as in those with $\mathrm{CH}_{2}$ and $\mathrm{CH}_{3}$, partly derived from the fact that the snails of one population simply mated more frequently than did the snails of the other population. However, interpopulational differences in mating propensity are often considered as a first step to reproductive isolation (e.g. Markow, 1981a; Meffert \& Bryant, 1991 and references therein). To diminish any influences of extreme differences in the snails' acclimatization to our experimental conditions, we used individuals from natural populations that were exposed to similar climatic conditions both in Sweden and in the Swiss Alps. Snails from the more benign conditions of the Swiss lowlands exhibited a significantly lower mating propensity than the animals used in the present study (B. Baur, unpublished observations).

Caution should be exercised in interpreting results of mate-choice tests for other reasons as well. For example, the experimental design employed can influence the frequency of matings, as demonstrated in salamanders of the genus Desmognathus (Verrell, 1990). We used a multiple-choice design, in which three (hermaphroditic) snails from each of two populations were put together and considered only the first mating pair, because in subsequent matings pair formation will be influenced by different numbers of homoand heterotypic partners available in the test arena. Field observations indicate that a multiple-choice design may represent a close approximation to the natural breeding conditions of high-density populations. Courting groups involving between three and five individuals have frequently been observed in natural populations (in Helix pomatia, Lind, 1988; in $A$. arbustorum, B. Baur, unpublished observations).

Furthermore, early mating experience can influence mate choice: females of Drosophila paulistorum with homotypic copulatory mating experience showed a significantly higher preference for homotypic males than those without mating experience (O'Hara et al., 1976). The snails used in the mate-choice tests were collected as adults from populations with relatively high densities. Thus, we assume that all snails had homotypic mating experience from the previous year(s).

The mechanism of mate discrimination in $A$. arbustorum is not yet known. Terrestrial gastropods are known to emit large amounts of chemicals (Croll, 1983). However, the use of pheromones for mate discrimination by terrestrial gastropods has hardly been studied to date (cf., Chelazzi, 1990), except in Achatina fulica, which does employ chemical cues for mate location (Chase et al., 1978). In the present study 
courting pairs seemed to attract other conspecifics. Attracted snails interfered with the courting pair and, in some cases, prevented copulation. In general, undisturbed pairs were able to bring courtship to the point of copulation more often. Laboratory experiments demonstrated that within the same population A. arbustorum does not discriminate between mating partners of different size and that a large shell size does not provide any advantage during courtship to increase mating success (Baur, 1992). In the present study, size differences of the six individuals tested in a trial did not exceed the range of shell size found within natural populations. Thus, the preferential mating with homotypic partners in snails from the populations $S_{1}$ and $\mathrm{CH}_{1}$, which differed in shell size, may not be attributable to size differences.

The fact that snails from a Swedish and a Swiss population preferred to mate with homotypic partners indicates partial premating isolation. However, the breeding experiment demonstrated a high degree of reproductive compatibility among individuals of these populations: heterotypic and homotypic pairs did not differ in the number of viable offspring produced. These results coincide with earlier findings of a high degree of reproductive compatibility even between remote populations of the land snail Cepaea nemoralis (Cook, 1967; Cain et al., 1968; Johnson et al., 1984). By contrast, in the freshwater snail Taphius (=Australorbis) glabratus, matings between conspecific individuals from the same population resulted in the production of cross-fertilized zygotes, while in crosses with individuals from populations separated by distances of 1700-1900 km self-fertilization frequently occurred (Paraense, 1959). Those results indicated a lowered fertility between remote populations of A. glabratus. Palmer et al. (1990) provided reproductive, morphological and genetic evidence that northern and southern populations of the rocky shore gastropod Nucella ( = Thais) emarginata of the northeastern Pacific belong to two reproductively isolated cryptic species. At the species level, reproductive isolation has arisen between sibling species of the land snail Partula in populations situated only a few kilometres apart from each other on the Polynesian island of Moorea (Murray \& Clarke, 1968; Johnson et al., 1977). The nature of the isolation mechanisms in Partula on Moorea and the causes of their breakdown in some places are still unknown. Johnson et al. (1977) assume that relatively simple behavioural differences may prevent interbreeding between largely compatible gene pools. However, because some pairs of species cross under laboratory conditions, reproductive incompatibility may not be complete among the Moorean species. Similar patterns of reproductive iso- lation have been found in Drosophila, which suggest that premating isolation may evolve more rapidly than postmating isolation (Powell, 1978; Markow, 1981b; Coyne \& Orr, 1989).

To summarize, mate-choice tests with $A$. arbustorum from distant populations indicated a certain preference for mating with partners from the same origin. In contrast, heterotypic pairs were capable of crossing; a reduced fertility was observed in one of two crosses. These results suggest a partly reduced compatibility in this species.

\section{Acknowledgements}

We thank $\mathrm{H}$. W. Waldén for sending us the snails from site $\mathrm{S}_{2}$. T. Birchler, X. Chen and D. Geiger provided technical assistance and A. J. Cain, J. J. D. Greenwood, A. P. Møller, P. Sjögren, S. Ulfstrand, A. van Noordwijk and an anonymous referee commented on the manuscript. Financial support was received from the Swiss National Science Foundation (grant No. 31-26258.89).

\section{References}

ADAMO, S. A. AND CHASE, R. 1990. The 'love dart' of the snail Helix aspersa injects a pheromone that decreases courtship duration. J. Exp. Zool., 255, 80-87.

ANT, H. 1969. Zur Würm-glazialen Ueberdauerung europäischer Landgastropoden in Eisrandnähe. Malacologia, 9, 249-250.

ARTER, H. E. 1990. Spatial relationship and gene flow paths between populations of the alpine snail Arianta arbustorum (Pulmonata:Helicidae). Evolution, 44, 966980.

BARTON, N. H. AND CHARLESWORTH, B. 1984. Genetic revolutions, founder effects, and speciation. Ann. Rev. Ecol. Syst., 15, 133-164.

BAUR, B. 1984. Shell size and growth rate differences for alpine populations of Arianta arbustorum (L.) (Pulmonata:Helicidae). Rev. Suisse Zool., 91, 37-46.

BAUR, B. 1986. Geographic variation of resting behaviour in the land snail Arianta arbustorum (L.): does gene flow prevent local adaptation? Genetica, 70, 3-8.

BAUR, B. 1988. Repeated mating and female fecundity in the simultaneously hermaphroditic land snail Arianta arbustorum. Invert. Reprod. Develop., 14, 197-204.

BAUR, B. 1990. Seasonal changes in clutch size, egg size and mode of oviposition in Arianta arbustorum (L.) (Gastropoda) from alpine populations. Zool. Anz., 225, 253-264.

BAUR, B. 1992. Random mating by size in the simultaneously hermaphroditic land snail Arianta arbustorum: experiments and an explanation. Anim. Behav., 43, (in press).

BAUR, B. AND BAUR, A. 1986. Proximate factors influencing egg cannibalism in the land snail Arianta arbustorum (Pulmonata, Helicidae). Oecologia (Berl.), 70, 283 287. BAUR, B. AND GOSTELI, M. 1986. Between and within population 
differences in geotactic response in the land snail Arianta arbustorum (L.) (Helicidae). Behaviour, 97, 147-160.

BAUR, B. AND RABOUD, C. 1988. Life history of the land snail Arianta arbustorum along an altitudinal gradient. J. Anim. Ecol., 57, 71-87.

BURLA, H. AND STAHEL, w. 1983. Altitudinal variation in Arianta arbustorum (Mollusca, Pulmonata) in the Swiss Alps. Genetica, 62, 95-108.

CAIN, A. J., SHEPPARD, P. M. AND KING, J. M. B. 1968. The genetics of some morphs and varieties of Cepaea nemoralis (L.). Phil. Trans. Roy. Soc. B, 253, 383-396.

CHASE, R., PRYER, K., BAKER, R. AND MADISON, D. 1978. Responses to conspecific chemical stimuli in the terrestrial snail Achatina fulica (Pulmonata:Sigmurethra). Behav. Biol., 22, 302-315.

CHELAzZI, G. 1990. Eco-ethological aspects of homing behaviour in molluscs. Etholo., Ecol. Evol., 2, 11-26.

COOK, L. M. 1967. The genetics of Cepaea nemoralis. Heredity, 22, 397-410.

COYNE, J. A. AND ORR, H. A. 1989. Patterns of speciation in Drosophila. Evolution, 43, 362-381.

CROLL, R. P. 1983. Gastropod chemoreception. Biol. Rev., 58, 293-319.

ENDlER, J. A. 1977. Geographic Variation, Speciation and Clines. Princeton University Press, Princeton, New Jersey.

HofMANN, E. 1923. Ueber den Begattungsvorgang von Arianta arbustorum (L.) Jena. Zeitsch. Naturw., 59, (N. F. 52), 363-400.

JOHNSON, M. S., CLARKE, B. C. AND MURRAY, J. 1977. Genetic variation and reproductive isolation in Partula. Evolution, 31, 116-126.

JOHNSON, M. S., STINE O. C. AND MURRAY, J. 1984. Reproductive compatibility despite large-scale genetic divergence in Cepaea nemoralis. Heredity, 53, 655-665.

KERNEY, M. P. AND CAMERON, R. A. D. 1979. A Field Guide to the Land Snails of Britain and North-West Europe. Collins, London.

LIND, H. 1988. The behaviour of Helix pomatia L. (Gastropoda, Pulmonata) in a natural habitat. Vidensk. Meddr. dansk. naturh. Foren., 147, 67-92.

MARKow, T. A. $1981 \mathrm{a}$. Courtship behavior and control of reproductive isolation between Drosophila mojavensis and Drosophila arizonensis. Evolution, 35, 1022-1026.

MARKOW, T. A. $1981 \mathrm{~b}$. Mating preferences are not predictive of the direction of evolution in experimental populations of Drosophila. Science, 213, 1405-1407.

MAYr, E. 1963. Animal Species and Evolution. Belknap Press, Cambridge, MA.

MEFFERT, L. M. AND BRYANT, E. H. 1991. Mating propensity and courtship behavior in serially bottlenecked lines of the housefly. Evolution, 45, 293-306.

MURRAY, J. AND ClARKE, B. C. 1968. Partial reproductive isolation in the genus Partula (Gastropoda) on Moorea. Evolution, 22, 684-698.

O'HARA, E., PRUZAN, A. AND EHRMAN, L. 1976. Ethological isolation and mating experience in Drosophila paulistorum. Proc. Nat. Acad. Sci., U.S.A., 73, 975-976.

OTTE, D. AND ENDler, J. A. (eds) 1989. Speciation and its Consequences. Sinauer Associates, Sunderland, MA.

PALMER, A. R., GAYRON, S. D. AND WOODRUFF, D. S. 1990. Reproductive, morphological, and genetic evidence for two cryptic species of Northeastern Pacific Nucella. Veliger, 33, 325-338

PARAENSE, W. L. 1959. One-sided reproductive isolation between geographically remote populations of a planorbid snail. Am. Nat., 93, 93-101.

POWELL, J. R. 1978. The founder-flush speciation theory: an experimental approach. Evolution, 32, 465-474.

SOKAL, R. R. AND ROHLF, F. J. 1981. Biometry, 2nd edn. Freeman, San Francisco.

SPIETH, H. T. AND RINGO, J. M. 1983. Mating behavior and sexual isolation in Drosophila. In: Ashburner, M., Carson, H. L. and Thompson, J. N. Jr. (eds) The Genetics and Biology of Drosophila, Academic Press, London, pp. 223-284.

VERRELL, P. A. 1990. Frequency of interspecific mating in salamanders of the plethodontid genus Desmognathus: different experimental designs may yield different results. J. Zool., Lond., 221, 441-451.

VERRELL, P. A. AND ARNOLD, S. J. 1989. Behavioral observations of sexual isolation among allopatric populations of the mountain dusky salamander, Desmognathus ochrophaeus. Evolution, 43, 745-755.

VISMARA, D. 1983. Enzympolymorphismus bei Arianta arbustorum-Populationen in den Schweizer Alpen. MS Thesis, University of Zürich.

WALDÉN, H. W. 1986. A comprehensive account of the Late Quaternary Land Mollusca in Scandinavia. Malakol. Abhand. Dresden, 11, 105-133. 